\title{
The Impact of Employee Involvement and Empowerment in Lean Manufacturing System Implementation towards Organizational Performances
}

\author{
Eida Nadirah Roslin", Shamsuddin Ahmed*, Mohamad Asmidzam Ahamat", Mohd Zaki Bahrom", \\ Norazlin Ibrahim ${ }^{\#}$

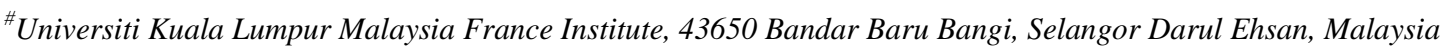 \\ Email: eidanadirah@unikl.edu.my
}

*Department of Mechanical and Chemical Engineering, Islamic University of Technology (IUT), Dhaka, Bangladesh

\begin{abstract}
Lean Manufacturing System (LMS) implementations in Malaysia's automotive industry has not been extensive in its expected reach, as extensive inquiries revealed it being adopted as a "pick-and-choose" system for certain processes or only upon determined levels within the industry. Current implementation strategy does not permit the industry to gain total benefits from the system itself. Undeniably, a few significant factors are being given less significance in multiple stages of LMS' execution. Employee involvement and employee empowerment have been identified as part of these contributing factors in a successful implementation of LMS in an organization. However, important criterion with its contributing aspects of these factors is not given the necessary attention, translating into a lamer impact upon companies embarking on a LMS deployment. This paper examines the impact of these two factors in the implementation of a lean manufacturing system towards achieving the organizational performances in the automotive industry. A questionnaire-survey was administered to gauge the impact of these two factors in an implementation process of a lean manufacturing system and later analyzing the effect towards their organizational performances. Data from 204 automotive parts manufacturers were gathered and analyzed. The correlation between the influencing factors, 5 lean activities and 6 organizational performances were measured. The results gained suggest that the integration between employee involvement and employee empowerment will be a valuable critical organizational capability impacting organizational performances towards the successful implementation of LMS in the Malaysian automotive industry.
\end{abstract}

Keywords - employee involvement; employee empowerment; lean manufacturing system; organizational performances.

\section{INTRODUCTION}

Within the Malaysian economic development context, the automotive industry is regarded as one of the most important sectors for productivity and growth. The government has strategically undertaken efforts in strengthening this industry. This has made the Lean manufacturing system a familiar concept in the domestic automotive community [1], [2]. However, until now, its implementation has still not encompassed the whole automotive sector [3]-[7]. Multiple factors are known as being contributable in making this system fulfilling an important role in an implementation process; at the same time, the ultimate goal of achieving total adoption among manufacturers. The factors of employee involvement and employee empowerment have been identified as part of these contributing factors [4], [8], [9]. These two factors are often taken lightly from the organizations, despite the desire of establishing a lean system in their operations [10].

Total involvement of employees is crucial; in fact, the implementation process will not grow without a workforce that works hand-in-hand. The implementation of LMS can only be successful when the total involvement from all level of employees in an organization was gained [9]. Crucially, there is a need for a complete understanding and a wide spread of LMS knowledge, to have total involvement and buy-in of employees towards a successful agenda. Invariably the management should experience a more fluid execution process of the intended implementation plans.

Job enrichment policies, worker's greater motivation, and responsibility were identified as factors that could lead to a complete failure of any LMS implementation initiatives if they are not understood or considered carefully. These issues are ironically the ones ignored by organizations, despite attempting to adopt and implement improvement initiatives 
[11]. Employee involvement factor needs the proper attention to make the implementation workable [12], [13].

Employee empowerment is another crucial factor in measuring the level of successful implementation of LMS in the organization [14]-[16]. Several studies have acknowledged and identified that empowerment can best be described as "a property of organizations, organizational teams, and groups as well as a property of individual employees" [9], [14], [17]-[22]. This statement objectifies the importance of employee empowerment has a transformational effect on an organization. As a consequence of employee empowerment, total involvement from employees is easily facilitated, thus conjured the management strategies to be executed effectively during an implementation [23]-[28]. It is believed that through empowerment, the employee's feels that being appreciated and will engage in organizational goals and consequently would spur collective commitment. This is crucially important as it has highly contributed to the organization achievement and performances.

Giving the empowerment to the employees does not mean to relinquish control, as guidelines and boundaries could be established to set limits of operations. Directional makers could guide employees to perform and operate in the right way, as liberty allows the workforce to utilize their own creative decision making and managing objectives [10]. Having trust and faith in the abilities and talents of their employees should be a positive approach to the management [17], [29]. Accordingly, this stand greatly reduces or eliminates unnecessary non-value added process or procedures, as it still allows contribution by employees towards the intended goals [30]. This is one of the most crucial factors within an LMS implementation and should not be ignored.

Based on the previous studies, factors related to the employee involvement and empowerment have had a strong specific weight in determining achievement levels for firms undertaking the LMS approach. The inter-reliability of these two factors and the proper functioning of both is required [22], [25], [26], [31]-[35]. Indeed, proper attention towards both factors is needed to make the implementation of LMS workable. In-line with that assumption, this study examines the impact of these two factors in the implementation of lean manufacturing system towards achieving the organizational performances in the automotive industry.

\section{MATERIALS AND METHOD}

\section{A. Conceptual Model Development}

For this study, a conceptual model was developed by examining the extensive amount of literature papers and reviews, in light of the various aspects of LMS implementation in the Malaysian automotive industry. The conceptual model highlights the relationship among the selected LMS factors, the LMS implementation activities and the organizational performances (Figure 1). Employee involvement and employee empowerment are recognized as the two influencing factors in LMS implementation. Just-InTime (JIT), Total Productive Maintenance (TPM), Quality Management (QM), Pull System (PS), Continuous Improvement (CI), and Design for Customer Need (DCN); are the 6 "lean dimensions" or activities are chosen to represent the major activities in a LMS implementation.

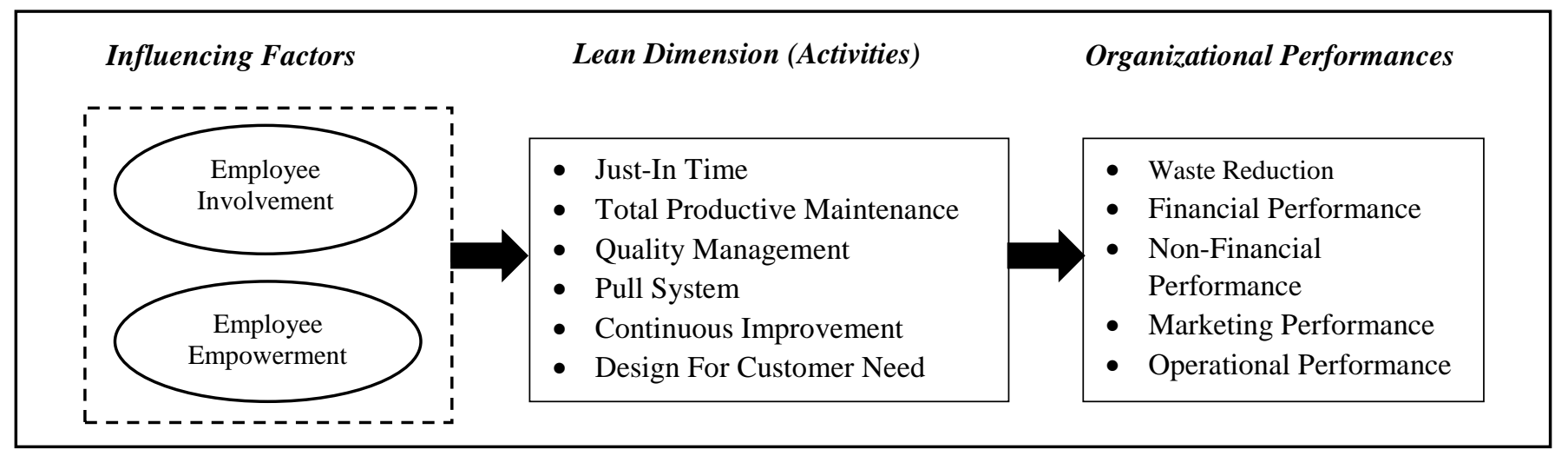

Fig. 1 Conceptual Model of LMS (Employee Involvement and Employee Empowerment) towards Organizational Performances

To gauge execution accomplishments, 5 organizational performances i.e. Waste Reduction (WR), Financial Performance (FP), Non-Financial Performance (NFP), Marketing Performance (MP) and Operational Performance (OM) were identified and measured. Figure 2 shows the sources of the selected lean dimensions ( 6 dimensions) and organizational performances ( 5 organizational performances) in this study. Two proposed hypotheses were developed in order to measure the impact of both factors in relation to LMS implementation.

- $H_{1}$ : Employee Involvement positively affects the level of LMS implementation
- $\mathrm{H}_{2}$ : Employees Empowerment positively affects the level of LMS Implementation

TABLE I

SOURCE OF LEAN DimENSIONS AND ORGANIZATIONAL PERFORMANCES [8]

\begin{tabular}{|l|l|}
\hline \multicolumn{1}{|c|}{ Variables } & \multicolumn{1}{c|}{ Source } \\
\hline \multicolumn{1}{|c|}{ Lean Dimensions } \\
\hline Just-In-Time (JIT) & $\begin{array}{l}\text { Flynn et al. (1995a, b), Koufteros et al. (1998), } \\
\text { Moyano et al. (2012a, b), Sakakibara et al. } \\
\text { (1997), Soriano and Forrester (2002), Ward } \\
\text { and Zhou (2006). }\end{array}$ \\
\hline $\begin{array}{l}\text { Total Productive } \\
\text { Maintenance (TPM) }\end{array}$ & $\begin{array}{l}\text { Dow et al. (1999), Moyano et al. (2012a, b), } \\
\text { Shah and Ward (2007) }\end{array}$ \\
\hline
\end{tabular}




\begin{tabular}{|l|l|}
\hline $\begin{array}{l}\text { Quality Management } \\
\text { (QM) }\end{array}$ & $\begin{array}{l}\text { Flynn et al. (1995a, b), Moyano et al. (2012), } \\
\text { Sakakibara et al. (1997), Soriano and Forrester } \\
\text { (2002). }\end{array}$ \\
\hline Pull System (PS) & $\begin{array}{l}\text { Shah and Ward (2003 and 2007), Sakakibara et } \\
\text { al. (1993), Ward and Zhou (2006). }\end{array}$ \\
\hline $\begin{array}{l}\text { Continuous } \\
\text { Improvement (CI) }\end{array}$ & $\begin{array}{l}\text { Koufteros et al. (1998), Li et al. (2005), Shah } \\
\text { and Ward (2003). }\end{array}$ \\
\hline $\begin{array}{l}\text { Design for Customer } \\
\text { Need (DCN) }\end{array}$ & $\begin{array}{l}\text { Ahmad et al. (2003), Cua et al. (2001), Flynn } \\
\text { et al. (1995a, b), Shah and Ward (2003). }\end{array}$ \\
\hline \multicolumn{2}{|c|}{ Organizational Performances } \\
\hline $\begin{array}{l}\text { Waste Reduction (WR) } \\
\text { Financial Performance } \\
\text { (FP) }\end{array}$ & $\begin{array}{l}\text { Fullerton and Wempe (2009), Yang et al. } \\
\text { (2011). }\end{array}$ \\
\hline $\begin{array}{l}\text { Mallerton and Wempe (2009), Yang et al. } \\
\text { (2011). }\end{array}$ \\
\hline $\begin{array}{l}\text { Performance (MP) } \\
\text { Perfinancial }\end{array}$ & $\begin{array}{l}\text { Konecny and Thun, (2011), Shah and Ward } \\
\text { (2003), Yang et al. (2011). }\end{array}$ \\
\hline $\begin{array}{l}\text { Operational } \\
\text { Performance (OP) }\end{array}$ & $\begin{array}{l}\text { Fullerton and Wempe (2009), Konecny and } \\
\text { Thun, (2011), Shah and Ward (2003), Yang et } \\
\text { al. (2011) }\end{array}$ \\
\hline
\end{tabular}

\section{B. Data Collection Activities - Questionnaire Administration}

A total of 350 automotive parts manufacturer companies were chosen for this study, which had received full support from the Malaysia Automotive Institute (MAI). Being a government organization, MAI presides over all related matters concerning the automotive industry. A questionnaire set was formed and adapted from previous studies conducted by Norani et al. [34], Shah and Ward [4], Fullerton and Wempe [35] and Yang et al. [36]. These questionnaires were distributed to the identified organization.

To ensure the data obtained were unbiased and accurate, the multiple key informant techniques were used in the data collection process [37]-[40], [45]. Targeted respondents were those possessing direct involvement and those having great familiarity with LMS implementation activities within the organization. As the data collection activity had been completed, the data was consolidated and analyzed using the Structural Equation Modeling (SEM) and the SPSS techniques.

\section{RESULTS AND DISCUSSION}

\section{A. Descriptive Statistics}

A total of 204 completed questionnaire was received, and this accounts for approximately 58.3 percent of completed responses for this study. Table 2 presents the demographic data for this study. About 58 percent of companies in Malaysia was established in 10 years and above. The assumption is that LMS being a state-of-the-art manufacturing system, its features should have been wellknown to them. Longer established periods, and larger outfits should rationally mean higher degrees of exposure to LMS and its factors, but this is not entirely the case. The data points that only 60 percent of these companies were locally-owned, while 28 percent had locals as majority owners. Most of these firms introduced about 1-3 new products per year. Years of involvement with LMS was quoted as only to be between 1-3 years for 47 percent of them. This highlights that most local automotive parts manufacturers have less than 5 years of LMS experience.
The discoveries through this study have unveiled that the Malaysian automotive industry is still far behind in their LMS implementation, as 62 percent of respondents further revealed of having a minor understanding with regards to the LMS concept and functionality.

\section{TABLE II}

DEMOGRAPHICS DATA AT MALAYSIAN AUTOMOTIVE PARTS ORGANIZATION

\begin{tabular}{|c|c|c|c|}
\hline Measurement & Items & Freq. & $\begin{array}{c}\text { Percentage } \\
(\%)\end{array}$ \\
\hline \multirow{5}{*}{$\begin{array}{l}\text { Organization } \\
\text { Maturity (Years) }\end{array}$} & $<5$ & 29 & 14.22 \\
\hline & $5-10$ & 56 & 27.45 \\
\hline & $10-15$ & 59 & 28.92 \\
\hline & $15-20$ & 43 & 21.08 \\
\hline & $>20$ & 17 & 8.33 \\
\hline \multirow{4}{*}{ Business Size } & $<50$ & 3 & 1.5 \\
\hline & $51-150$ & 59 & 28.9 \\
\hline & $151-250$ & 78 & 38.2 \\
\hline & $>250$ & 64 & 31.4 \\
\hline \multirow{4}{*}{ Business Ownership } & $\begin{array}{c}\text { Malaysian } \\
(100 \%)\end{array}$ & 123 & 60.3 \\
\hline & $\begin{array}{c}\text { Foreign } \\
(100 \%) \\
\end{array}$ & 18 & 8.8 \\
\hline & $\begin{array}{c}\text { More } \\
\text { Malaysian } \\
\end{array}$ & 58 & 28.4 \\
\hline & More Foreign & 5 & 2.5 \\
\hline \multirow{4}{*}{$\begin{array}{l}\text { Introduce New } \\
\text { Product per Year }\end{array}$} & 1 to 3 & 123 & 60.3 \\
\hline & 4 to 6 & 50 & 24.51 \\
\hline & 7 to 9 & 20 & 9.80 \\
\hline & $>10$ & 11 & 5.40 \\
\hline \multirow{4}{*}{ Involved in LMS } & $<1$ year & 0 & 0 \\
\hline & 1-3 years & 95 & 46.57 \\
\hline & 3-5 years & 46 & 22.55 \\
\hline & $>5$ years & 13 & 6.37 \\
\hline
\end{tabular}

\section{B. Confirmatory Factor Analysis - Lean Manufacturing} Activities

The CFA was performed in order to measure the correlation of the six LMS activities - JIT, TPM, QM, PS, CI, and DCN. The results of the CFA (first-order) analysis model is fit. Table 3 illustrated the inter-correlation matrix of measurement analysis for LMS implementation activities.

TABLE III

INTER-CORRELATIONS MATRIX OF LMS IMPLEMENTATION ACTIVITIES

\begin{tabular}{|c|c|c|c|c|c|c|}
\hline & JIT & TPM & QM & PS & CI & DCN \\
\hline JIT & $\mathbf{0 . 7 0 6}$ & & & & & \\
\hline TPM & 0.698 & $\mathbf{0 . 8 0 7}$ & & & & \\
\hline QM & 0.694 & 0.737 & $\mathbf{0 . 8 0 1}$ & & & \\
\hline PS & 0.589 & 0.652 & 0.709 & $\mathbf{0 . 7 5 2}$ & & \\
\hline CI & 0.683 & 0.668 & 0.701 & 0.643 & $\mathbf{0 . 8 0 1}$ & \\
\hline DCN & 0.629 & 0.657 & 0.634 & 0.605 & 0.672 & $\mathbf{0 . 8 1 2}$ \\
\hline
\end{tabular}


The LMS sub-dimensions converge on a single latent factor was tested by using the second-order CFA. The results suggest that the second-order CFA of LMS implementation is fit. Table 4 shows the overall CFA results of the correlation matrix in LMS implementation activities.

TABLE IV

CFA MEASUREMENT OF LEAN MANUfaCtURING System IMPLEMENTATION

\begin{tabular}{|c|c|c|c|c|}
\hline Construct & 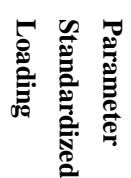 & 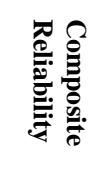 & 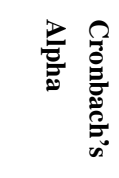 & $\begin{array}{l}\text { Average } \\
\text { Variance } \\
\text { Extracted }\end{array}$ \\
\hline $\begin{array}{l}\text { Lean } \\
\text { Manufacturing }\end{array}$ & & 0.923 & 0.889 & 0.666 \\
\hline JIT & 0.809 & & & \\
\hline TPM & 0.841 & & & \\
\hline QM & 0.862 & & & \\
\hline PS & 0.784 & & & \\
\hline CI & 0.823 & & & \\
\hline DCN & 0.775 & & & \\
\hline
\end{tabular}

\section{Confirmatory Factor Analysis - Organizational Performances}

The correlation of the organizational performances (WR, FP, MP, NFP, and OP) were also examined using the CFA. The analysis result for first-order CFA shows that the model is fit. Table 5 illustrated the correlation matrix of measurement analysis for organizational performances.

TABLE V

Organizational Performance - CoRrelation Matrix MEAsurement ANALYSIS

\begin{tabular}{|l|l|l|l|l|l|}
\hline & WR & FP & MP & NFP & OP \\
\hline WR & $\mathbf{0 . 7 5 9}$ & & & & \\
\hline FP & 0.692 & $\mathbf{0 . 7 7 0}$ & & & \\
\hline MP & 0.624 & 0.729 & $\mathbf{0 . 7 8 4}$ & & \\
\hline NFP & 0.619 & 0.589 & 0.679 & $\mathbf{0 . 7 4 5}$ & \\
\hline OP & 0.720 & 0.605 & 0.681 & 0.656 & $\mathbf{0 . 7 6 3}$ \\
\hline
\end{tabular}

The business performance sub-dimensions converge on a single latent variable was tested by performing the secondorder CFA. Overall results are demonstrated in Table 6. The second-order CFA of organizational performance is fit.

TABLE VI

CFA MEASUREMENT OF ORGANIZATIONAL PERformanCES

\begin{tabular}{|c|c|c|c|c|}
\hline Constructs & 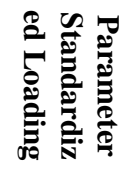 & 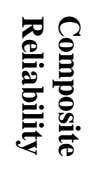 & 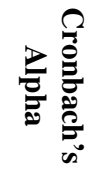 & 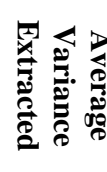 \\
\hline $\begin{array}{c}\text { Lean } \\
\text { Manufacturing }\end{array}$ & & 0.906 & 0.864 & 0.659 \\
\hline
\end{tabular}

\begin{tabular}{|c|c|l|l|l|}
\hline WR & 0.815 & & & \\
\hline FP & 0.807 & & & \\
\hline MP & 0.837 & & & \\
\hline NFP & 0.776 & & & \\
\hline OP & 0.824 & & & \\
\hline
\end{tabular}

\section{A Structural Model Assessment}

Accordingly, the structural model test includes the test of structural path fitness [40], which are estimates of the path coefficients that are indicating the strengths of the relationships between the dependent and independent variables [40], and the $R^{2}$ values, which represent the amount of variance explained by the independent variables [39]. The acceptable structural path fitness satisfied the cutoff values of the goodness of fit indices of the structure model. $(\mathrm{RMSEA}=0.030, \mathrm{CMIN} / \mathrm{DF}=1.179, \mathrm{RMR}=0.023$, $\mathrm{SRMR}=0.049$ ), and all the incremental fit indices reach the respective acceptable threshold values $(\mathrm{CFI}=0.967$, IFI= 0.968 , $\mathrm{TLI}=0.968, \mathrm{GFI}=0.800, \mathrm{NFI}=0.822$, and $\mathrm{RFI}=$ 0.806). Similarly, the structural model suggests an adequate structural since $\Delta X 2=1319.597-1302.197=17.400$ (the difference between Chi-Square values) is very insignificant. The significance of the relationship of research variables and the standardized path coefficients in $\mathrm{H} 2$ (employee empowerment) is shown in Table 7. The relationships are strongly supported. Conversely, there is no significant relationship between employee involvements as a factor influencing the implementation of LMS, which further indicates that $\mathrm{H} 1$ is rejected. Table 7 revealed the assessment of hypotheses in this study.

TABLE VII

RESULTS OF HYPOTHESES TESTS

\begin{tabular}{|l|l|l|l|}
\hline Hypothesis & Relationship & $\beta$ & Support \\
\hline $\mathrm{H}_{1}$ & $\begin{array}{l}\text { Employee } \\
\text { Involvement } \\
\rightarrow \text { Lean } \\
\text { Manufacturing } \\
\text { Implementation }\end{array}$ & -0.084 & NO \\
\hline $\mathrm{H}_{2}$ & $\begin{array}{l}\text { Employee } \\
\text { Involvement } \\
\rightarrow \text { Lean } \\
\text { Manufacturing } \\
\text { Implementation }\end{array}$ & $0.221^{* *}$ & \\
\hline
\end{tabular}

One of the two tested had an insignificant result (employee involvement), which contradicts findings in other literature reviews. High levels of employees' involvement in LMS-related activities among Malaysian automotive part manufacturers, had not translated to higher LMS implementation level. This fact challenges the findings of a majority of prior studies [43-44], which largely signifies the existence of positive consequence of employee involvement over LMS implementation. This could be attributable to a lack of autonomy being given to the employees [44]. This circumstance can be considered as a disadvantage for Malaysian automotive part manufacturers. Despite the importance of employee's involvement businesses have yet been able to adequately manage in creating active participation towards diverse lean manufacturing activities, for their employees. 
Consideration should be given towards effective involvement, as it would enable employees to change easily resulting from LMS implementation. As these automotive part manufacturers undertake the change process, their structure and management system need to be modified to integrate higher staff involvement at all levels effectively. This should be in terms of problem-solving and decisionmaking process during the implementation of differing LMS stages and activities. Through this approach, employees would feel the freedom of working at their authority and acting according to their abilities. This reduces the resistance towards change and in turn, encourages active participation in problem-solving activities; the situation which is often termed as a dominant element needed for world-class manufacturing [44].

Viewed from the shop-floor perspective, the findings suggest the existence of a significant positive relationship between employees' empowerment and LMS implementation; this supports the second hypothesis (H2), inherent among the Malaysian automotive part manufacturers. This finding explains that employee's empowerment toward the implementation of lean manufacturing is needed in order to achieve the successful implementation within an organization. Employees' selfefficacy or confidence is naturally elevated during accomplishment of task objectives in different lean activities, by allotting increased levels of employee empowerment [4344]. An empowerment strategy is believed to free employees at different levels of dictated controls which is often obligatory in adherence to a firm's set policies and strategies. Having the ability to be responsible for their ideas, decisions, and actions; results in an energized workforce with an enhanced competence. This should conjure the determination to perform all tasks that continuously meet or exceed the expectation of internal and external customers.

\section{CONCLUSIONS}

This study has managed to gather industry information, develop two specific hypotheses and conduct multiple analyses. The prior conceptual model was further refined and tested, to determine LMS' relevance within the proposed model. All noticeable performance improvements were consolidated and given focus to deduce its sustainability is moving forward into the future.

Through this study, it suggested that there should be a significant relationship between Employee Empowerment and the level of LMS implementation in Malaysian automotive industry. The empirical findings support the real perspective that effective implementation of lean manufacturing activities will provide performance improvement and improve different metrics [4], [8], [19], [43]-[44], for adopting firms within the Malaysian automotive part manufacturers group.

In essence, an organization could implement the following, in order to increase employee empowerment and adherence to the agenda:

1) Organizational work culture change: Top management should have higher levels of trust in the decisions of their employees. Especially if they are working in their expertise areas.
2) Build Trust and Mutual Interest: Management and employees, sharing the same mission could focus on achieving customer satisfaction. Lean is a team activity that requires every team member to understand their role and thus executing their job to the best of their ability, training, and expertise.

3) Appreciation: management needs to adopt an appreciative nature and value their employees more, for their commitment to achieving the organizational goals.

4) Reward-based incentives: Employees are rewarded and recognized for empowered behavior, in order to give their discretionary energy in fulfilling the organizational performances.

A conducive environment must be created for employees who are keen to participate and are highly involved in leancentric activities, through working groups, suggestion schemes, top-down communications and employee - friendly policies.

This fosters a better work-culture and allows higher participation in lean practices, problem-solving and decision-making. Effective empowerment allowed to employees encourages strategic thinking and gives them the liberty to make sound judgments concerning their job scope or job function, to add crucial inputs in different lean practices, continues creative problem-solving and decisionmaking activities. Hence employee involvement and employee empowerment can be highly described as important influencing factors in achieving success towards full implementation of LMS in the Malaysian automotive industry.

\section{ACKNOWLEDGMENT}

This research was supported by the Ministry of Higher Education Malaysia under Fundamental Research Grant Scheme, project no: FRGS/1/2015/TK03/UNIKL/02/1. We would like to thank Malaysia Automotive Institute for providing us the expertise that greatly assisted the research.

\section{REFERENCES}

[1] Santos, Z.G.d., L. Vieira, and G. Balbinotti, Lean Manufacturing and Ergonomic Working Conditions in the Automotive Industry. Procedia Manufacturing, 2015. 3: p. 5947-5954.

[2] De Felice, F. and A. Petrillo, Optimization of Manufacturing System through World Class Manufacturing. IFAC-Papers Online, 2015. 48(3): p. 741-746.

[3] Vinodh, S., \& Joy, D., Structural Equation Modelling of Lean Manufacturing Practices. International Journal of Production Research, 2012. 50(6).

[4] Shah, R. and P.T. Ward, Defining and developing measures of lean production. Journal of Operations Management, 2007. 25(4): p. 785805.

[5] Sanjay Bhasin, P.B., Lean Viewed as a Philosophy. Journal of Manufacturing Technology Management, .2006. 17(1): p. 56-72.

[6] Deflorin, P., \& Scherrer-Rathje, M., Challenges in the Transformation to Lean Production from different ManufacturingProcess Choices: a Path-Dependent Perspective International Journal of Production Research, 2011 p. 1-18.

[7] Pius, A., Esam, S., Rajkumar, R., \& Geoff, N., Critical Success Factors for Lean Implementation within SMEs Journal of Manufacturing Technology Management, 2006. 17(4): p. 460-471.

[8] Eida Nadirah Roslin, A Model for Full-Blown Implementation of Lean Manufacturing System in Malaysian Automotive Industry, Unpublished PhD Thesis, 2013, Faculty of Engineering, University of Malaya, Kuala Lumpur, Malaysia. . 
[9] Pius, C.A., Development of an Impact Assessment Framework for Lean Manufacturing within SMEs. Unpublished PhD Thesis 2007, CRANFIELD UNIVERSITY.

[10] Perumal Puvaneswaran, H.M., Tang Sai Hong, \& Razali, M. M. , Lean Process Management Implementation through Enhanced Problem Solving Capabilities Journal of Industrial Engineering and Management, 2010. 3(3): p. 447-493.

[11] Pun, K., Chin, K., \& Gill, R., Determinants of Employee Involvement Practices in Manufacturing Enterprises. Total Quality Management, 2001. 12(1): p. 95-109.

[12] Ugboro, I.O., \& Obeng, K. , Top Management Leadership, Employee Empowerment, Job Satisfaction, and Customer Satisfaction in TQM Organizations: An Empirical Study Journal of Quality Management, 2000. 5(2): p. 247-272.

[13] Da'vid, L., Krisztina, D., \& Jenei, L. N., Factors Influencing Employee Perceptions in Lean Transformations. Int. J. Production Economics, 2011. 131: p. 30-43.

[14] Farris, J.A., Van Aken, E. M., Doolen, T. L., \& Worley, J., Critical Success Factors for Human Resource Outcomes in Kaizen events: An Empirical Study International Journal of Production Economics, 2009. 117(1): p. 42-65.

[15] Holden, L., The Perception Gap in Employee Empowerment: A Comparative Study of Banks in Sweden and Britain. . Personnel Review, 1999. 28(3): p. 222 - 241

[16] Mabry, B.G. and K.R. Morrison, Transformation to lean manufacturing by an automotive component supplier. Computers \& Industrial Engineering, 1996. 31(1-2): p. 95-98.

[17] Shah, R. and P.T. Ward, Lean manufacturing: context, practice bundles, and performance. Journal of Operations Management, 2003. 21(2): p. 129-149.

[18] Balakrishnan, J., J.B. Eliasson, and T.R.C. Sweet, Factors affecting the evolution of manufacturing in Canada: An historical perspective. Journal of Operations Management, 2007. 25(2): p. 260-283.

[19] Holweg, M., The genealogy of lean production. Journal of Operations Management, 2007. 25(2): p. 420-437.

[20] Jannis, A., Robert, C., Cary, C., \& Colin, G., Building a HighCommitment Lean Culture Journal of Manufacturing Technology Management, 2010. 22(5): p. 569-586.

[21] Rosalind, F., Implications of Lean Manufacturing for Human Resource Strategy. Work Study 1995. 44(3): p. 20-24.

[22] Farris, J.A., et al., Critical success factors for human resource outcomes in Kaizen events: An empirical study. International Journal of Production Economics, 2009. 117(1): p. 42-65.

[23] Glover, W.J., et al., Critical success factors for the sustainability of Kaizen event human resource outcomes: An empirical study. International Journal of Production Economics, 2011. 132(2): p. 197213.

[24] Losonci, D., K. Demeter, and I. Jenei, Factors influencing employee perceptions in lean transformations. International Journal of Production Economics, 2011. 131(1): p. 30-43.

[25] Zhao, X., et al., The impact of internal integration and relationship commitment on external integration. Journal of Operations Management, 2011. 29(1-2): p. 17-32.

[26] Gulshan, C., \& Singh, T. P., Measuring Parameters of Lean Manufacturing Realization. Measuring Business Excellence, 2012. 16(3): p. 51-65

[27] Jayaram, J., Vickery, S., \& Droge, C., Relationship Building, Lean Strategy, and Firm Performance: An Exploratory Study in the Automotive Supplier Industry. International Journal of Production Research, 2008. 46(20): p. 5633-5649.
[28] L. Jawahar, N., \& Gary D, H., Assessment of Organisationa Involvement in Implementing Empowerment. Integrated Manufacturing Systems, 2002. 13(4): p. $201-211$.

[29] Papadopoulou, T.C., \& Â-zbayrak, M., Leanness: Experiences from the Journey to Date. Journal of Manufacturing Technology Management, 2005. 16(7): p. 784-807

[30] Paul, S., Andy, D., Mike, R., \& Valeria, P., Workers' Experiences of Skill, Training and Participation in Lean and High-Performance Workplaces in Britain and Italy. Employee Relations, 2010. 32(6): p 606-624.

[31] Tomas, B., \& Juan, A. M.-G., Integrating Human Resource Management into Lean Production and their Impact on Organizational Performance. International Journal of Manpower, 2011. 32(8): p. 923-938

[32] Tung; A., Baird; K., \& Schoch, H. P., Factors Influencing the Effectiveness of Performance International Journal of Operations \& Production Management, 2011.31(12): p. 1287-1312.

[33] Bhasin, S., Performance of Lean in large organizations. Journal of Manufacturing Systems, 2012. 31(3): p. 349-357.

[34] Norani Nordin, B.M.D., \& Dzuraidah Abdul Wahab., A Survey on Lean Manufacturing Implementation in Malaysian Automotive Industry International Journal of Innovation, Management, and Technology, 2010. 1(4): p. 7.

[35] Fullerton, R.R., \& Wempe, W. F., Lean Manufacturing, NonFinancial Performance Measures, and Financial Performance International Journal of Operations \& Production Management, 2009. 29(3): p. 214-240

[36] Yang, M.G., P. Hong, and S.B. Modi, Impact of lean manufacturing and environmental management on business performance: An empirical study of manufacturing firms. International Journal of Production Economics, 2011. 129(2): p. 251-261.

[37] Anderson, J.C., \& Gerbing, D. W., Structural Equation Modeling in Practice: A Review and Recommended Two-Step Approach. Psychological Bulletin, 1998. 103(3): p. 411-423.

[38] Fornell, C. and F.L. Bookstein, Two structural equation models: LISREL and PLS applied to consumer exit-voice theory. Journal of marketing research, 1982. 19(4): p. 440-452.

[39] Ho, R., Handbook of univariate and multivariate data analysis and interpretation with SPSS. 2006, New York: CRC Press.

[40] Hair, J.F., et al., Multivariate Data Analysis. 6 ed. 2006: Upper Saddle River, NJ: Prentice Hall.

[41] Rai, A., R. Patnayakuni, and N. Seth, Firm performance impacts of digitally-enabled supply chain integration capabilities. MIS Quarterly, 2006. 30(2): p. 225-246.

[42] Sohal, A.S., Developing a Lean Production Organization: An Australian Case Study. International Journal of Operations \& Production Management, 1996. 16(2): p. 91-102.

[43] Pun, K., K. Chin, and R. Gill, Determinants of employee involvement practices in manufacturing enterprises. Total Quality Management, 2001. 12(1): p. 95-109.

[44] Ugboro, I.O. and K. Obeng, Top management leadership, employee empowerment, job satisfaction, and customer satisfaction in TQM organizations: an empirical study. Journal of Quality Management, 2000. 5(2): p. 247-272.

[45] G. Arcidiacono and A. Pieroni, The Revolution Lean Six Sigma 4.0. International Journal on Advanced Science Engineering Information Technology, 2018. 8(1): p. 141-149 